\title{
Exploring Cultural Differences in Implementing International Technology Transfer In the Case of Japanese Manufacturing Subsidiaries in Vietnam
}

\author{
Nguyen Thi Duc Nguyen \\ Ritsumeikan University \\ E-Mail: ntducnguyen@yahoo.co.jp \\ Atsushi Aoyama \\ Ritsumeikan University \\ E-Mail: aoyama@mot.ritsumei.ac.jp
}

\begin{abstract}
This study investigates how Japanese management practices are affected by Vietnamese culture through international technology transfer implementation at Japanese manufacturing subsidiaries located in Vietnam. The concept of technology transfer refers to the transfer of cross-cultural production management systems. Utilizing Abo's framework on Japanese management systems and Hofstede's theory of cultural dimensions, we applied a qualitative data collection approach, including multiple specific methods-in-depth interviews, group discussions, and observations - to conduct an empirical inquiry at 13 Japanese manufacturing subsidiaries in Vietnam. The obvious effects of Vietnamese culture on the current Japanese management style as it relates to internal work organization and administration were mainly observed in group consciousness, the seniority system, job classification, job rotation, training and education, quality control, and hiring policy. The Collectivism and Power Distance dimensions derived from two contradictory characteristics of Vietnamese culture-its community spirit and autonomy-are the most important aspects of those effects. It is suggested that professionals and expatriates become aware of the cultural challenges and opportunities, decide which managerial elements should be adjusted, and which aspects should be kept through technology transfer, based on a consideration of which cultural differences provide conflicts and which provide benefits. This study also offers insights to help managers
\end{abstract}


flexibly adapt Japanese management to Vietnam's environment.

Keywords: Vietnam, International Technology Transfer Implementation, Cultural Difference, National Culture, Japanese Subsidiaries

\section{INTRODUCTION}

Vietnam has recently become one of the fastest growing economies in Asia. To meet this situation, the main challenge is how to catch up with and maintain the great speed of technological change in a situation where the capacity for technological investment remains insufficient. Vietnam has focused more attention on attracting direct foreign investment since initiating an economic reform process in 1986. In light of this, the Japanese have taken a long-term perspective, and invested in developing countries like Vietnam to take advantage of exports, and to increase firms' profits by enlarging the manufacturing network overseas. Moreover, due to the increasing costs of production in Japan, the incentives for direct investment and the efforts of entering into alliance networks as equity-based partnerships to expand the geographic for production activities and to deepen the supply networks already existing in the ASEAN has been attractive (Beamish, Delios, \& Lecraw, 1997; Mallet, 1999). Therefore, Japanese managers have been eager to transfer the Japanese management style to developing countries, particularly Vietnam, through international technology transfer projects. Actually, Japanese management practices in Vietnam differ from the original Japanese management style, however, and the transfers have thus been modified through technology transfer. To date, the research of cross-cultural technology transfer as well as cross-cultural Japanese management practices focusing on Japanese firms in Vietnam is inadequate. This situation leads us to ask two questions. How can the Japanese management style be transferred successfully during the performance of technology transfer projects from Japan to developing countries? Why must Japanese management practices adjust to local culture?

To explore the uniqueness of the Japanese management style in the context of Vietnamese culture, this study takes a critical look at the cultural dimensions based on Hofstede's (2010) conceptual framework, used along side well-known Japanese management practices based on Abo's (1994) framework. We constructed the study according to the empirical inquiry approach by integrating multiple specific methods-in-depth interviews, group discussions, and observations- to investigate the influence of Vietnamese culture on Japanese management practices within the real-life contexts of cross-cultural technology transfer. Additionally, this paper considers that the object of technology transfer is a management style, and that 
technology transfer is a complex process of transferring know-how and management practices - in our case, Japanese production management-across organizational borders from developed to less technologically developed countries.

The study is organized as follows. First, a brief introduction to the issues is presented. Then, the relevant research literature on cross-cultural technology transfer and cross-cultural Japanese management practices is briefly presented. Next, Abo's (1994) framework on the Japanese management system and Hofstede's (2010) national culture dimensions are described in detail. The empirical design framework and the qualitative data collection approaches, including in-depth interview, group discussion, and observation, and the data collection target on Japanese subsidiaries are also presented in this section. The next section presents and discusses the obvious effects of Vietnamese culture on the Japanese management style at Japanese subsidiaries in Vietnam, when transferring Japanese-style production management systems through technology transfer. The internal work organization and administration occur mainly in the group consciousness, the seniority system, job classification, job rotation, training and education, quality control, and hiring policy; thus, they will be our focus. Finally, some practical conclusions and overall points for further research are offered in the conclusion.

\section{RELEVANT RESEARCH}

This study constitutes an intersection of two research fields concerning cross-cultural technology transfer and cross-cultural Japanese management practices. Following the approach of Creswell (2009), the current literature can be summarized as follows.

Firstly, in the context of cross-cultural technology transfer, much prior quantitative research has investigated the factors inhibiting and facilitating knowledge and technology transfer in cross-cultural business contexts, but these works have covered only a few dimensions, such as the characteristics of the knowledge, the suppliers and recipients, and their relationships (e.g., Rebentisch \& Ferretti, 1995; Pak \& Park, 2004; Le \& Evangelista, 2007; Sazali, Raduan, Jegak, \& Haslinda, 2009). Some studies have indicated the importance of national culture in the cross-cultural knowledge transfer process (e.g., Simonin, 1999; Holden, 2002; Pauleen, Wu, \& Dexter, 2007). Others have pointed out that cultural difference and distance are the key obstacles and the roots of cultural conflicts and misunderstandings in inter-firm knowledge and technology transfer (e.g., Lyles \& Salk, 1996; Mowery, Oxley, \& Silverman, 1996; Lin \& Berg, 2001, Le \& Evangelista, 2007). However, relatively 
few exploratory studies have suggested theoretical frameworks for explaining how national culture affects knowledge transfer and technology transfer using Hofstede's culture dimensions (e.g., Bhagat, Kedia, Harveston, \& Triandis, 2002; Lucas, 2006, Chen, Sun, \& McQueen, 2010; Nguyen, Takanashi, \& Aoyama, 2012; Nguyen \& Aoyama, 2012).

Secondly, in the context of cross-cultural Japanese management practices, there are few insights into how Japanese manufacturers adjust their successful production methods on the locational, regional, or spatial level (Schlunze, 1992; Schlunze, 2002). Some studies have taken culture-based approaches to examine the impact of Japanese-style management on Japanese multinational companies (e.g., Yoshino, 1976; Trevor, 1983; Swierczek \& Onishi, 2003; Dore, 2011), or to analyze the potential for the international transfer of Japanese production systems (e.g., Abo, 1994; Ishida, 1986; Koike, 1988). While acknowledging that the Japanese-style production system is difficult to transfer successfully, these studies have not yet explored the issues sufficiently and deeply from Hofstede's national culture perspective and other cultural aspects.

In short, studies on cross-cultural technology transfer and cross-cultural Japanese management practices have mainly aimed to explain the nature of international technology transfer, and have lacked a synthetic and systematic view incorporating both theoretical and empirical approaches. The key issues, which have yet to be conceptualized adequately, are how local national cultures affect Japanese management practices, how Japanese managers adjust their management styles to match local cultures, and how they decide which managerial elements should be adjusted, and which components should be kept through international technology transfer. This study, using empirical inquiry, seeks to explore those problems through the lens of national culture.

\section{FUNADAMENTAL THEORY}

This study is underpinned by two fundamental theories. One is Abo's framework for Japanese management practices, in which the eight critical elements relating to internal work organization and administration are focused-group consciousness, wage system, promotion, job classification, job rotation, training and education, quality control, and hiring policy. The other is Hofstede's five cultural dimensions theory-Individualism, Power distance, Uncertainty avoidance, Long-term orientation, and Masculinity. They are summarized as follows. 


\section{Abo's Framework for Japanese Management Practices.}

Among the works on Japanese management practices in hybrid factories, the theoretical framework introduced by Abo (1994) is remarkably valuable to an understanding of the execution of the Japanese management style overseas. Seven categories need to be understood. (1) "Work organization and administration" refers to job classification, the wage system, job rotation, education and training for engineers and factory workers, and the promotion of first-line supervisors. (2) "Production control" refers to quality control, maintenance, operating management, and production equipment. (3) "Procurement" refers to local content, relation with suppliers, and procurement methods. (4) "Group consciousness" refers to small group activities, information sharing, and the sense of unity. (5) "Labor relations" refers to hiring policy, job security, labor unions, and grievance procedures. (6) "Parent-subsidiary relations" refers to the ratio of Japanese expatriates, delegation of authority, and the managerial positions of Japanese and local partners. (7) "Community relations" refers to participation in local economic organizations, donations and volunteer activities on behalf of local communities, and competition with local companies.

This study herein uses Abo's framework to explore how Japanese managerial practices occurred during the transfer of Japanese production management systems through technology transfer at Japanese subsidiaries in Vietnam. Among mentioned seven categories with various managerial items, this study only focuses on the following eight critical elements of the core Japanese management system that relate to internal work organization and administration: group consciousness, wage system, promotion, job classification, job rotation, training and education, quality control, and hiring policy.

\section{Hofstede's National Culture}

Hofstede's work has come in for some criticism: (1) the sampling approach is fixed at one company that may not generate information applicable to the entire cultural system of any country (McSweeney, 2002); (2) the timing axis of the survey may have been sensitive to the time, particularly to the dimension of Masculinity and Uncertainty avoidance (Newman \& Nollen, 1996; Jones \& Alony, 2007); (3) measuring by survey is not a proper method of determining cultural disparity, especially in the case of measured variables relating to culturally sensitive and subjective topics (McSweeney, 2002; Schwartz, 1999); (4) the statistical analysis used the same questionnaire item for more than one scale, and was comprised of 32 questions with only 40 country cases (Dorfman \& Howell, 1988); (5) cultural 
homogeneity is assumed for the whole national domestic population while most nations have various ethnicities and beliefs (McSweeney, 2002; Jones \& Alony, 2007); and, (6) national division is not an appropriate analyzing unit, as cultures are not necessarily bounded by borders (McSweeney, 2002). Nevertheless, Hofstede's work has been remarkably helpful to scholars and practitioners in explaining differences in work-related values, and has been used in studies of cross-cultural management and international business systems (Michael \& College, 1997; Schlunze, Hyttel-Srensen, \& Ji, 2011). Its relevance for scholarly work on culture is its rigorous design, systematic collection, coherent theory, and the relative accuracy of its cultural dimensions (Jones \& Alony, 2007).

This study uses Hofstede (2010)'s theory of five cultural dimensions as a fundamental reference point to explore the effects of the Vietnamese management perspective on the Japanese management style through a national culture lens. The key dimensions are Individualism, Power distance, Uncertainty avoidance, Long-term orientation, and Masculinity.

(1) Individualism vs. Collectivism is the measure of whether people in a community prefer to work in groups or as individuals. It indicates the degree of interdependence between the members of a society, and the strength of the ties that bind individuals into cohesive groups or social networks. It describes personal relationships, teamwork skills, individual success compared to that of colleagues, the importance of maintaining harmony and saving face, loyalty, and the sense of duty towards the work community, superiors, and subordinates.

(2) Masculinity vs. Femininity does not absolutely refer to the dominance of gender. It defines the roles society assigns to the two sexes, and the attitudes towards masculine and feminine leadership styles. It also refers to valuing achievement, confidence, material wealth, personal relations, dividing work time and free time, defining the quality of work life, the importance of work for an individual, and the expectations and methods of promotion.

(3) Power distance refers to the degree of hierarchy in workplaces, and the distances among social strata. It refers to the degree to which a society's members can tolerate inequality in the distribution of power and wealth within organizations. It also refers to the significance of status differences, the acceptance of the leader's authority, the necessity for guidance and leadership, the values attached to age, and the manner of presenting feedback.

(4) Uncertainty avoidance refers to the extent to which people are threatened by a lack of structure or uncertain events, a society's need to control unknown situations, 
and a society's ability to handle uncertainty and maintain balance. It refers to the way people deal with the future, and whether events are inherently controlled or beyond their control, particularly in terms of timing and punctuality, planning, reactions to planning changes and rule-breaking, ways of expressing emotions in public, the acceptance of different opinions and kinds of people, and the necessity for rules, models, standards, and rituals in the work environment.

(5) Long-term orientation refers to how much society values long-term strategies. It refers to setting objectives, vision, and the timing of tasks and goals.

In short, to investigate the most significant points in the behaviors and attitudes of Vietnamese employees and managers concerning the Japanese management style during technology transfer implementation, this study has focused on the five primary cultural dimensions referred above; the remaining dimensions are beyond our scope.

\section{RESEARCH METHOD}

This study has been constructed according to the empirical inquiry approach by integrating multiple specific methods-in-depth interviews, group discussions, and observations-to investigate the influence of Vietnamese culture on Japanese management practices within the real-life contexts of cross-cultural technology transfer at Japanese manufacturing subsidiaries in Vietnam. At the same time, complementary techniques were used in the interviews, such as introductory questions, probing questions, direct and indirect questions, and interpretive questions, together with the explanation of unclear issues. These approaches are the most effective, especially when the boundaries between phenomena and contexts are not evident (Yin, 2009).

The eight critical elements of the core Japanese management system in Abo's framework-group consciousness, wage system, promotion, job classification, job rotation, training and education, quality control, and hiring policy - and the five national culture dimensions provided by Hofstede (2010)-Individualism, Masculinity, Power distance, Uncertainty avoidance, and Long-term orientation - were used as a foundation for designing the empirical inquiry framework (see Figure 1) that guided the interviews and discussions. Based on this framework, semi-structured questions were designed to address the core research questions below.

How have the behaviors and attitudes of Vietnamese employees and managers originating from their own national culture affected the Japanese management style during the technology transfer implementing process at Japanese subsidiaries in Vietnam? 
Sub-question 1: How is the Japanese management style in Vietnam different from the original Japanese management style?

Sub-question 2: How do the differences between the Japanese management style in Vietnam and the original Japanese management style originate from Vietnamese culture?

This study applied the purposeful sampling method targeting Japanese manufacturing subsidiaries in mechanical industries located in the tech parks of Southern Vietnam. The criteria for selecting the companies for research were primarily based on their business fields in Vietnam. They are as follows: equipment for asphalt road-building, butt-welding fittings used in various infrastructural capacities, aluminum extrusion dies, stamping dies, internal components for hydraulic equipment, precision parts, steel ball welding, plastic mold segments, and multidisc torque converters for cars.

First, three pilot studies using in-depth interviews of an average duration of 3.5 hours were conducted to access a rich source of first-hand knowledge, verify the research method, and confirm that the questions could meet the research objectives, revise ambiguous questions, and improve the techniques for the later official in-depth interviews. Then, the eight official in-depth interviews (two with senior Japanese managers, and six with Vietnamese production managers), and five focus group discussions were held. The small focus group discussions (three to six people) occurred at the work locations during the middle stages of the research, and at neutral locations during the final stages. This method created an environment that was comfortable and conducive to discussion and argument, allowing an observation of the interactions of many participants, stimulating new ideas, and providing information on subconscious behavior (Goulding, 2002). Seven senior Japanese managers and 23 Vietnamese engineering and production managers at several departments in 13 Japanese subsidiaries took part in the in-depth interviews, and focus group discussions. Participants were on average 45 years old, with an average of 11 years of experience in international technology transfer. The average length of the in-depth interviews was 2 hours, and 3.5 hours for the focus group discussions. The direct observation technique was added to the interviews and group discussions in order to gain in-depth information from subjects' actions rather than their words, especially in cases where subjects had not expressed their feelings on their cross cultural technology transfer experience verbally.

Data from the in-depth interviews, focus group discussions, and observations were compiled through extensive notes taken at the time, and rewritten later the same 
day. The data were analyzed and interpreted by a circular process of description, classification, and connection, as in Dey (1993). Specifically, the collected data were described, classified, conceptually ordered, analytically generalized, and checked for coherency using Hofstede's dimensions and Abo's framework (see Figure 1). The number of companies was increased gradually as the findings grew, obtaining stability after five months of intensive research investigation.

\section{ACTUAL MANAGERIAL PRACTICES IN VIETNAM AND THEIR RATIONALE}

On the basis of the interviews and observations, this section presents and discusses the actual managerial practices at Japanese subsidiaries in Vietnam when transferring Japanese-style production management systems through technology transfer implementation. The national culture fundamentals of Vietnam, based on Hofstede's five cultural dimensions, are used to explain the rationale behind the adjustments made to match the behaviors and attitudes of Vietnamese employees and managers. The discoveries about the effects of Vietnamese culture on the current Japanese management style through this empirical inquiry are summarized in Table 1 that mainly lie in group consciousness, seniority system, job classification, job rotation, on-the-job-training for engineers and factory workers, quality control, and hiring policy. They lie mainly within the Collectivism and Power Distance dimension deriving from two contradictory characteristics of Vietnamese culture - community spirit and autonomy. They will be presented in detail in following parts.

\section{Group Consciousness}

The sense of togetherness and the voluntary participation in activities to improve work processes are the critical characteristics of the Japanese management system (Schunze, 2002). In their interviews, Japanese managers stated that the Vietnamese staff did not seem pleased with consensual decision-making in the Japanese management style. Therefore, Japanese managers usually obtain consensus directly among Japanese executives and group leaders, those who can communicate well in Japanese or English. Vietnamese managers believe that consensual decision-making should occur only to overcome the gap between Japanese management and the Vietnamese during technology transfer implementation. Actually, Vietnamese employees feel a strong sense of competition. If they experience discontent or disagreements at work, a non-harmonic sense easily emerges. 


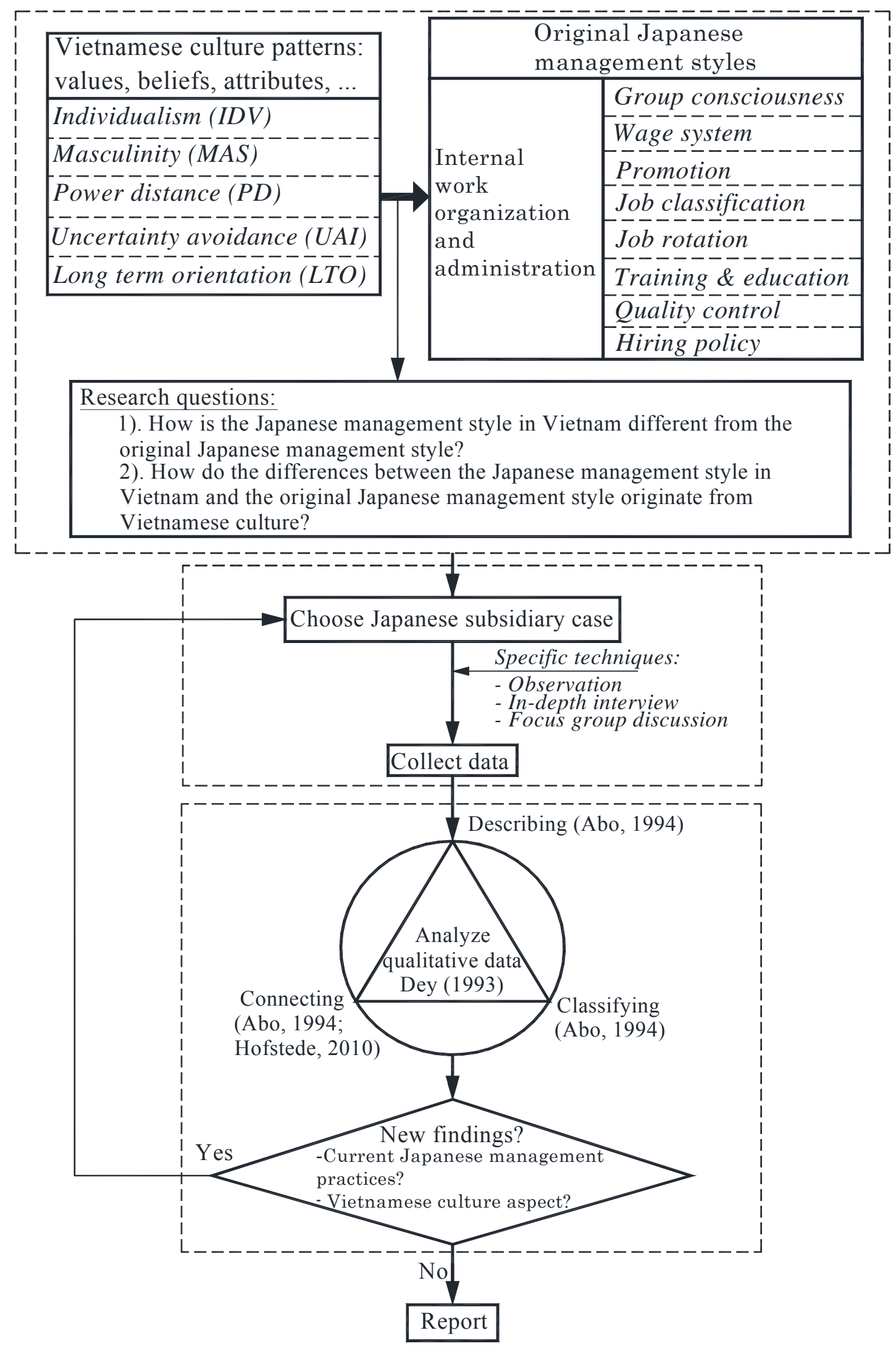

Figure 1 Analytical Research Framework 
This happens because of two contradictory native characteristics-community spirit (low Individualism) and autonomy (high Power distance) — both advantageous and disadvantageous and co-existing in the Vietnamese culture (Tran, 1996). Despite their various modes of cooperation and strong solidarity, Vietnamese attitudes and behavior tends to allow for wide latitude and room for individual discretion at work. In addition, the basis of the Vietnamese community spirit is the autonomous village, where each village people feels an intimacy and mutual support only within itself, existing quite independently from the others. Thus, Japanese companies often obtained the group consciousness through small group activities with a leader.

Accordingly, Vietnamese managers suggested that it is necessary to use key group leaders with comprehensive knowledge in both the communication and professional realms to obtain the opinions of local workers and of each member in the small groups.

\section{Seniority System}

The Japanese seniority system is based on a wage system and promotion. It is rigidly applied to evaluate a worker's performance according to working time and age. The longer one stays with a company, the higher one's wage will be. Promotion is driven by age and years of work rather than one's level of work achievement.

Vietnamese staff claimed that the seniority system discourages employees, especially the younger ones, who expect that hard work and contributing intellectually will speed their promotion. Vietnamese managers believe that the success of an organization is usually associated with individual initiative. Indeed, this attitude originates from the traditional notion of Vietnamese autonomy, which emphasizes differentiation according to power distance and individual ability. In addition, Vietnamese workers, with traits derived from agricultural life and the habit of dialectical thinking, form positive and negative principles and exhibit dualistic and synthetic behavior (Tran, 1996). In Vietnamese culture, a low Masculinity emphasis is placed on working to receive personal rewards or incentives worth the effort spent, balancing personal and working life, and other matters.

In fact, Japanese managers recognize that, although Japanese companies have often preferred longtime employees who stick faithfully to the company and have desired to retain their own seniority system, performance-based rewards through personal performance evaluations, however, would be more suitable to their Vietnamese staff. Therefore, the seniority wages are also adjusted by adding the seniority allowance, but not so much. They prefer individual rewards to be recognized 
in a positive way-openly, frankly, and fairly. The bonuses are paid one per year, about 1 to 3 months' salary. Blue-collar wages are determined by job classification and labor grade, and the wage system is adjusted each year according to Vietnamese material labor laws and labor unions. White-collar salaries are also increased about $10-20 \%$ depending on the business situation of the company and the seniority.

Furthermore, Vietnamese managers said that Japanese general managers usually only promote the Japanese professionals to executive positions rather than Vietnamese professionals, regardless of their performance. For Vietnamese management level, the promotion is done by the immediate superior, and is based on work experience, seniority (usually up one level per 3 years), and with the test of intensive skills and live interview.

\section{Job Classification}

Japanese-style job classification is not related to wages or promotion. In Vietnam, though, the basic wage is indexed to job classification and background education. From the interviewees' point of view, Japanese managers stated that their job assignment and classification methods on the shop floor were not as difficult as the Vietnamese ones. They have applied multiple tasks/lines of work for one employee, for example as accountant cum office administration, technical staff cum production management, quality control. In fact, Japanese managers usually decided on how to divide the work in most cases. Thus, Japanese executives usually employ their own way in company's job classification practices through small consultants and the involvement of the Vietnamese management. Based on the interviews, we could conclude that adjusting to Vietnamese culture was not their preferred tactic. An aspect of the low uncertainty avoidance of Vietnamese culture, adventurousness, can be used to explain the flexibility in accepting new and different work. This is one view of the Individualism dimension that emphasizes demonstrating individual ability in organization's success.

\section{Job Rotation}

Job rotation, for Japanese management, aims to change work among different work groups in order to create many skilled workers, achieve innovation in multiple areas, and avoid monotony at work. Vietnamese workers prefer fixed work in one professional field with the related powers and managements. This comes from the high power distance of Vietnamese culture that strongly emphasizes autonomy. Indeed, the Vietnamese attitudes and behavior can cause problems with selfishness, 
balkanization, factions, and the "local village spirit" (Tran, 1996). Another issue is the patriarchal and hierarchical mind that creates the idea that "your elder brother replaces your father," imposing responsibilities, encouraging "long life to the aging" (Tran, 1996). Usually, Japanese managers in Vietnam expect job rotation across different work groups frequently, and select capable employees to handle significant work assignments. In fact, job rotation has regularly been only partly applied with selected persons in groups or conducted within one group. Japanese companies tried to practice job rotation among different work departments, but with a changeover period of usually 3 years each for key technicians and managers at various levels, and shorter for workers, normally from 3 to 6 months. One aspect of the low uncertainty avoidance of Vietnamese culture is adventurousness, synthetic thinking, and a flexible style that defines their receptive attitude (Tran, 1999). They are eager to follow new opportunities. Therefore, Japanese managers acknowledge that their Vietnamese employees easily adapt to new assignments and quickly. Thus, Vietnamese managerial staff and workers can do more, be flexible, understand the work of each other, and can be moved back and forth easily when people leave a job.

\section{On-the-Job-Training (OJT) for Engineers and Factory Workers}

The interviewees stated that there are two essential training methods that can help Vietnamese staff understand the Japanese work ethic: (1) training in the fundamental technical knowledge to operate and to set up machinery in the manufacturing system; and, (2) and training in the fundamental managerial knowledge needed for quality control, maintenance performance, and the proper procedures for product and process quality improvement. For Japanese expatriates, using OJT is the best way to ensure production performance, achieve product quality with close attention to operations, and improve working attitudes and operating skills. The Vietnamese culture with Individualism and Power distance dimension, that its characteristic privatization, factions, and local village spirit, emphasizes the differences originating from autonomy (Tran, 1996), and has a tradition of hard work and learning to survive in uncertain circumstances (Tran, 1999). They wish to have managerial roles to lead the company. Therefore, to conduct OJT efficiently, Japanese subsidiaries usually send Vietnamese engineers and technicians to the parent company in Japan for around 3 to 6 months to learn the background and practical operations; those employees play an important part in the technology transfer process, especially in local training. Moreover, Japanese technical experts and trained engineers train the Vietnamese workers at the local factories to ensure their efficient performance. 


\section{Quality Control}

The strength of the Japanese management system is the efficient production of high quality products (Schlunze, 2002). The slogan "doing it right the first time" and "zero defects" along with their high sense of responsibility are the elements Japanese expatriates want their Vietnamese staff to adopt, which would then allow them to apply the quality control methods used in Japan. The interviewees emphasized that Vietnamese employees complain that its quality practices are the most difficult portion of the Japanese management system for them to practice, because it is based on the viewpoint of voluntarism, especially in its corrective and preventive measures. Vietnamese workers would prefer that these quality-control activities occur during working hours rather than their free time. This derives from their philosophy of balance and traits derived from their agricultural life, and their habit of dialectical thinking (Tran, 1996; Pham, Vu, \& Tran, 2001). Vietnamese workers, with their Femininity culture, value balance in the process of working to receive value worth the effort spent, and a balance between personal and work life. Unfortunately for them, quality departments are usually divided into quality control and quality improvement groups, with quality issues found during one shift handed in detail during the following shift, with each shift changing every 8 hours.

In addition, the interviews reveal that Vietnamese management pays less attention to quality practices. The downside of flexibility here is arbitrary behavior, originating from synthetic and dialectical thinking combined with the group principles of the Vietnamese (Tran, 1999). At most of the plants, the inspectors play important roles in the product quality process, either in the production line or in deliveries to customers. The interviewees also stressed that the local management of mechanical processing factories frequently proposes quality control with inspectors or supervisors to make certain every product arriving to the client is high quality. The Vietnamese culture with high power distance, subordinates tolerate inspection and distribution of power at work. Their low uncertainty avoidance and long-term orientation (as per Hosftede's data) suggest that Vietnamese workers will be reluctant to make decisions and will require highly structured work routines. It is thus necessary to create a structure with clear rules and guidelines for them.

\section{Hiring Policy}

Japanese expatriates follow a non-dismissal policy for the sake of stability at their companies, but Vietnamese management prefers dismissal when necessary. A Vietnamese manager said that the lifetime employment system discourages flexible 
innovation, providing less benefit to highly educated employees' careers, though also easing their minds through the prospect of job security. This reveals high power distance in Vietnamese beliefs, which originate from traditional Vietnamese autonomy with its emphasis on differentiation, separation between management group and worker, professional and skilled education. At the same time, lifetime employment is also valued, particularly by unremarkable workers who have attained only a high school education, shown diligence, maintained good health and have been trained into skilled managers. This is explained by the dialectical thinking inherent in farming life of the Vietnamese. Therefore, there are now two popular kinds of hiring policy: (1) long-term contracts, approximating Japanese lifetime employment, priority for technicians and key managers (from the basic to top managerial level) who have the working experience and Japanese skills; and, (2) short-term contracts (from one to three years), renewable at the end of each period, for workers.

Briefly, Japanese managers tried to employ Japanese management practices, but from experience within Vietnam, they have become more eager to apply a flexible Japanese-style system along with the local system.

Table 1 The Japanese management style with respect to Vietnamese culture

\begin{tabular}{|c|c|c|c|}
\hline $\begin{array}{c}\text { Critical } \\
\text { managerial } \\
\text { elements }\end{array}$ & $\begin{array}{l}\text { Original Japanese } \\
\text { management style }\end{array}$ & $\begin{array}{c}\text { Actual Japanese management } \\
\text { style }\end{array}$ & $\begin{array}{c}\text { Dimension of Vietnamese } \\
\text { culture }\end{array}$ \\
\hline $\begin{array}{l}\text { Group } \\
\text { consciousness }\end{array}$ & $\begin{array}{l}\text {-Sense of } \\
\text { togetherness and } \\
\text { voluntary } \\
\text { participation in } \\
\text { most activities. }\end{array}$ & $\begin{array}{l}\text {-Small group activity with } \\
\text { leader. } \\
\text {-Consensual decision making } \\
\text { between Japanese executives } \\
\text { and group leaders. } \\
\text {-Take care in promotion of } \\
\text { key group leaders. }\end{array}$ & $\begin{array}{l}\text {-Individualism: } \\
\text { cooperation and strong } \\
\text { solidarity, but allow for } \\
\text { wide latitude and room } \\
\text { for individual discretion } \\
\text { at work. } \\
\text {-Power distance: intimacy } \\
\text { and mutual support only } \\
\text { within itself. }\end{array}$ \\
\hline
\end{tabular}


Table 1 The Japanese management style with respect to Vietnamese culture (Continued)

\begin{tabular}{|c|c|c|c|}
\hline $\begin{array}{l}\text { Critical } \\
\text { managerial } \\
\text { elements }\end{array}$ & $\begin{array}{l}\text { Original Japanese } \\
\text { management style }\end{array}$ & $\begin{array}{l}\text { Actual Japanese management } \\
\text { style }\end{array}$ & $\begin{array}{c}\text { Dimension of Vietnamese } \\
\text { culture }\end{array}$ \\
\hline Seniority system & $\begin{array}{l}\text {-The person who } \\
\text { has worked longer } \\
\text { with the company } \\
\text { will have the higher } \\
\text { wage. } \\
\text {-Promoted by age; } \\
\text { the younger person } \\
\text { with stronger } \\
\text { abilities will not be } \\
\text { promoted to a } \\
\text { position higher than } \\
\text { one held by an } \\
\text { older person. } \\
\text {-Reward group } \\
\text { success rather than } \\
\text { individual success. }\end{array}$ & $\begin{array}{l}\text {-Adjust the wage system } \\
\text { each year according to } \\
\text { Vietnamese material labor } \\
\text { laws and labor unions. } \\
\text { Increase about } 10-20 \% \\
\text { depending on the business } \\
\text { situation. } \\
\text {-Performance-based rewards } \\
\text { according to personal } \\
\text { performance evaluation. } \\
\text {-Rewards for individuals are } \\
\text { recognized in a positive } \\
\text { way-openly, frankly, and } \\
\text { fairly. } \\
\text {-The bonuses are paid one } \\
\text { per year, about } 1 \text { to } 3 \text { months' } \\
\text { salary. } \\
\text {-The promotion is done by } \\
\text { the immediate superior and is } \\
\text { based on work experience, } \\
\text { seniority (usually up one } \\
\text { level per } 3 \text { years). } \\
\text { - Flexible Japanese-style } \\
\text { system and local-style } \\
\text { system. }\end{array}$ & $\begin{array}{l}\text {-Individualism: individual } \\
\text { initiative. } \\
\text {-Masculinity: working to } \\
\text { receive personal rewards } \\
\text { or incentives worth the } \\
\text { effort spent. } \\
\text {-Power distance: } \\
\text { differentiation according } \\
\text { to power distance. }\end{array}$ \\
\hline $\begin{array}{l}\text { Job } \\
\text { classification }\end{array}$ & $\begin{array}{l}\text {-Job classification } \\
\text { is not related to } \\
\text { wages or } \\
\text { promotion. }\end{array}$ & $\begin{array}{l}\text {-Not much adjustment. } \\
\text {-Apply multiple work for one } \\
\text { employee, e.g., accountant } \\
\text { cum office administration, } \\
\text { technical staff cum } \\
\text { production management, } \\
\text { quality control. }\end{array}$ & $\begin{array}{l}\text {-Uncertainty avoidance: } \\
\text { adventurousness, eager to } \\
\text { take new chance, less care } \\
\text { about risk. } \\
\text {-Individualism: to } \\
\text { demonstrate individual } \\
\text { ability in organization's } \\
\text { success. }\end{array}$ \\
\hline
\end{tabular}


Table 1 The Japanese management style with respect to Vietnamese culture (Continued)

\begin{tabular}{|c|c|c|c|}
\hline $\begin{array}{l}\text { Critical } \\
\text { managerial } \\
\text { elements }\end{array}$ & $\begin{array}{l}\text { Original Japanese } \\
\text { management style }\end{array}$ & $\begin{array}{c}\text { Actual Japanese management } \\
\text { style }\end{array}$ & $\begin{array}{c}\text { Dimension of Vietnamese } \\
\text { culture }\end{array}$ \\
\hline Job rotation & $\begin{array}{l}\text {-Change work } \\
\text { among different } \\
\text { work groups to } \\
\text { create many skilled } \\
\text { workers and avoid } \\
\text { monotony at work. }\end{array}$ & $\begin{array}{l}\text {-Job rotation applied only } \\
\text { partly with selected persons } \\
\text { in groups or conducted } \\
\text { within one group. }\end{array}$ & $\begin{array}{l}\text {-Uncertainty avoidance: } \\
\text { adventurousness, } \\
\text { synthetic thinking and a } \\
\text { flexible style define their } \\
\text { receptive attitude. } \\
\text {-Power distance: prefer } \\
\text { fix work in one } \\
\text { professional field with the } \\
\text { related powers and } \\
\text { managements. }\end{array}$ \\
\hline $\begin{array}{l}\text { On-the-job- } \\
\text { training }\end{array}$ & $\begin{array}{l}\text {-The best way to } \\
\text { secure production } \\
\text { is on-the-job- } \\
\text { training }\end{array}$ & $\begin{array}{l}\text {-Train the key Vietnamese } \\
\text { technician in Japan from } 3 \text { to } \\
6 \text { months, who will train } \\
\text { Vietnamese workers under } \\
\text { the supervision of Japanese } \\
\text { experts in the early stage. }\end{array}$ & $\begin{array}{l}\text {-Individualism: the } \\
\text { differentiation in } \\
\text { individual ability. } \\
\text {-Power distance: the } \\
\text { differentiation in } \\
\text { managerial role leading } \\
\text { company. }\end{array}$ \\
\hline Quality control & $\begin{array}{l}\text {-Require high sense } \\
\text { of responsibility for } \\
\text { the efficient } \\
\text { production of high } \\
\text { quality products. }\end{array}$ & $\begin{array}{l}\text {-Group for quality control } \\
\text { and group for quality } \\
\text { improvement. } \\
\text {-Supervisors for each } \\
\text { production area. }\end{array}$ & $\begin{array}{l}\text {-Power distance: } \\
\text { subordinates tolerate } \\
\text { inspection and } \\
\text { distribution of power at } \\
\text { work. } \\
\text {-Long-term orientation } \\
\text { and Uncertainty } \\
\text { avoidance: } \\
\text { adventurousness, pay less } \\
\text { attention to quality } \\
\text { practices. } \\
\text {-Masculinity: value } \\
\text { balance in the process of } \\
\text { working and a balance } \\
\text { between personal and } \\
\text { work life. }\end{array}$ \\
\hline Hiring policy & $\begin{array}{l}\text {-Lifetime } \\
\text { employment }\end{array}$ & $\begin{array}{l}\text {-Long-term contract: the } \\
\text { working experience and } \\
\text { Japanese skills. } \\
\text {-Short-term contract: workers } \\
\text { who are less education, good } \\
\text { health, diligence. }\end{array}$ & $\begin{array}{l}\text {-Power distance: emphasis } \\
\text { on autonomy, } \\
\text { differentiation, separation } \\
\text { between management group } \\
\text { and worker, professional and } \\
\text { skilled education. }\end{array}$ \\
\hline
\end{tabular}




\section{CONCLUSION}

This study has revealed two remarkable findings: (1) the obvious effects of Vietnamese culture on the Japanese management style relating to internal work organization and administration lie mainly in group consciousness, the seniority system, job classification, job rotation, training and education, quality control, and hiring policy; and, (2) the Collectivism and Power Distance dimensions deriving from two contradictory characteristics of Vietnamese culture - community spirit and autonomy - carry the most important elements of those effects. It is concluded that transferring the Japanese management system to other national contexts through technology transfer implementation is not significantly difficult if it respects the existing conditions of each country, notably its cultural aspects.

We would propose two practical implications. (1) Japanese and local managers should consider integrating local norms and values into the Japanese management style. By learning and understanding the five basic national culture dimensions of Hofstede's framework, they can become of aware of the cultural challenges and opportunities. International managers could then discover how best to adjust the Japanese management practices. Moreover, gaining an adequate knowledge of the local and host cultures will allow Japanese and local managers to decide which managerial elements should be adjusted and which should be kept through technology transfer, based on a consideration of the cultural differences causing conflict and those producing benefits. (2) To transfer the core Japanese management style to overseas subsidiaries successfully, the Japanese expatriate should have the knowledge and abilities needed to manage the new cultural environment. Professionals and expatriates must design flexible practical approaches to overcome problems, and turn issues flowing from national cultural realities into advantages for the efficient transfer of technology.

Interest in the cross-cultural technology transfer research is still quite high and remains the most valuable area of study for both academics and managerial practitioners. Particularly, further research on the effect of national culture on the transfer and implementation of the Japanese management style overseas should pursue the following angles. (1) The remaining dimensions of Hofstede's framework or other aspects of national culture, such as individual behavior, intellectual values, and leadership values (Matsumoto \& Yoo, 2006), as well as the managerial elements of Abo's framework besides internal work organization and administration should be considered to obtain more insights. (2) A qualitative approach focusing on how to utilize the local culture to create the proper Japanese management style would be an 
interesting object of inquiry. (3) Further complementary approaches, both qualitative and quantitative, should aim to explore how current Japanese management practices at Japanese subsidiaries overseas affect a firm's business performance, and evaluate the adjusted strategies and locational preferences of overseas Japanese executive management with respect to their firms' productivity.

This study has provided insights to help managers flexibly adapt Japanese management to Vietnam, an issue to which previous research has paid insufficient attention.

\section{ACKNOWLEDGEMENT}

We gratefully acknowledge the generous Grant in Aid for International Research Activities provided by the Ritsumeikan Kokusaiteki Research Fund, and the Japanese Ministry of Education, Science, and Culture. We would like to acknowledge the invaluable support of the Vietnamese production managers and Japanese directors and thank them for their intensive interviews and eager cooperation. We would also like to express our deep gratitude to Prof. Bui Nguyen Hung, and Dr. Tran Thi Kim Loan for their assistance during the experimental period in Vietnam.

\section{REFERENCES}

Abo, T. (1994). Hybrid factory: The Japanese production system in the United States. New York, Oxford: Oxford University Press.

Beamish, P. W., Delios, A., \& Lecraw, D. J. (1997). Japanese multinationals in the global economy. Cheltenham, U. K.: Edward Elgar Publishing Limited.

Bhagat, R. S., Kedia, B. L., Harveston, P. D., \& Triandis, H. C. (2002). Cultural variations in the cross-border transfer of organizational knowledge: An integrative framework. The Academy of Management Review, 27(2), 204-221. http://dx.doi.org/10.2307/4134352.

Chen, J., Sun, P., \& McQueen, R. (2010). The impact of national cultures on structured knowledge transfer. Journal of Knowledge Management, 14(2), 228-242. http://dx.doi.org/10.1108/13673271011032373.

Creswell, J. W. (2009). Research design: Qualitative, quantitative and mixed methods approaches (3rd ed.). Los Angeles: Sage Publications.

Dey, I. (1993). Qualitative data analysis: A user-friendly guide for social scientists. London: Routlege. http://dx.doi.org/10.4324/9780203412497.

Dore, R. (2011). British factory-Japanese factory: The origins of national diversity in industrial relations (1st ed.). Abingdon: Routledge. 
Dorfman, P. W., \& Howell, J. P. ( 1988). Dimensions of national culture and effective leadership patterns: Hofstede revisited. In R. N Farmer \& E. G. McGoun (Eds.), Advances in international comparative management (Vol. 3, pp. 127-149). Greenwich, CT: JAI Press.

Goulding, C. (2002). Grounded theory: A practical guide for management, business and market researchers. London: Sage Publications Ltd.

Hofstede, G., Hofstede, G. J., \& Minkov, M. (2010). Cultures and organizations: Software of the mind: Intercultural cooperation and its importance of survival (3rd ed.). New York: McGraw-Hill.

Holden, N. (2002). Cross-cultural management: A knowledge management perspective. Harlow: Financial Times Prentice Hall.

Ishida, H. (1986). Transferability of Japanese human resource management abroad. Human Resource Management. 25(1), 103-120. http://dx.doi.org/10.1002/hrm.3930250108.

Jones, M., \& Alony, I. (2007). The cultural impact of information systems- through the eyes of Hofstede- a critical journey. Issues in Informing Science and Information Technology, 4, 407-419.

Koike, K. (1988). Understanding industrial relations in modern Japan. Basingstoke: Macmillan.

Le, N. H., \& Evangelista, F. (2007). Acquiring tacit and explicit marketing knowledge from foreign partners in IJVs. Journal of Business Research, 60(11), 1152-1165. http://dx.doi.org/10.1016/j.jbusres.2007.04.006

Lin, B. W., \& Berg, D. (2001). Effects of cultural difference on technology transfer projects: An empirical study of Taiwanese manufacturing companies. International Journal of Project Management, 19(5), 287-293. http://dx.doi.org/10.1016/S0263-7863(99)00081-2.

Lucas, L. M. (2006). The role of culture on knowledge transfer: The case of the multinational corporation. The Learning Organization, 13(3), 257-275. http://dx.doi.org/10.1108/09696470610661117.

Lyles, M. A., \& Salk, J. E. (1996). Knowledge acquisition from foreign parents in international joint ventures: An empirical examination in the Hungarian context. Journal of International Business Studies, 27(5), 877-903. http://dx.doi.org/10.1057/palgrave.jibs.8490155

Mallet, V. (1999). The trouble with tigers: The rise and fall of Southeast Asia. London: HarperCollins. 
Matsumoto, D., \& Yoo, S. H. (2006). Toward a new generation of cross cultural research. Association for Psychological Science, 1(3), 234-250. http://dx.doi.org/10.1111/j.1745-6916.2006.00014.x

McSweeney, B. (2002). Hofstede's model of national cultural differences and their consequences: A triumph of faith - A failure of analysis. Human Relations, 55(1), 89-118. http://dx.doi.org/10.1177/0018726702055001602.

Michael, J., \& College, W. (1997). A conceptual framework for aligning managerial behaviors with cultural work values. International Journal of Commerce \& Management, 7(3/4), 81-101. http://dx.doi.org/10.1108/eb047357.

Mowery, D. C., Oxley, J. E., \& Silverman, B. S. (1996). Strategic alliances and inter-firm knowledge transfer. Strategic Management Journal, 17(Winter Special Issue), 77-91.

Newman, K. L., \& Nollen, S. D. (1996). Culture and congruence: The fit between management practices and national culture. Journal of International Business Studies, 27(4), 753-779. http://dx.doi.org/10.1057/palgrave.jibs.8490152.

Nguyen, T. D. N., \& Aoyama, A. (2012). Does the hybridizing of intercultural potential facilitate efficient technology transfer? An empirical study on Japanese manufacturing subsidiaries in Vietnam. Asian Social Science, 8(11), 26-43. http://dx.doi.org/10.5539/ass.v8n11p26

Nguyen, T. D. N., Takanashi, C., \& Aoyama, A. (2012). Can efficient technology transfer be achieved through a hybrid corporate culture? A study on Japanese manufacturing subsidiaries in Vietnam. International Journal of Business and Management, 7(7), 24-39. http://dx.doi.org/10.5539/ijbm.v7n7p

Pak, Y., \& Park, Y. (2004). A framework of knowledge transfer in cross-border joint ventures: An empirical test of the Korean context. Management International Review, 44(4), 435-455.

Pauleen, D. J., Wu, L. L., \& Dexter, S. (2007). Exploring the relationship between national and organizational culture, and knowledge management. In D. J. Pauleen (Ed.), Cross-cultural perspectives on knowledge management (pp. 3-19). London: Libraries Unlimited Press.

Pham, V. N., Vu, H., \& Tran, T. T. (2001). Van hoa trong kinh doanh [Culture in business]. Ho Chi Minh city: Labor Publication.

Rebentisch, E. S., \& Ferretti, M. (1995). A knowledge asset-based view of technology transfer in international joint ventures. Journal of Engineering and Technology Management, 12(1-2), 1-25. http://dx.doi.org/10.1016/0923-4748(95)00002-4. 
Sazali, A. W., Raduan, C. R., Jegak, U., \& Haslinda, A. (2009). Effects of inter-firm technology transfer characteristics on degree of inter-firm technology transfer in international joint ventures. European Journal of Scientific Research, 35(3), 474-491.

Schlunze, R. D. (1992). Spatial diffusion of Japanese firms in West Germany and West Berlin from 1995 to 1989. Geographical Review of Japan, 65(1), 32-56

Schlunze, R. D. (2002). Locational adjustment of Japanese management in Europe. $\begin{array}{llll}\text { Asian Business \& } \quad \text { Management, 267-283. } & \text { 1(2), }\end{array}$ http://dx.doi.org/10.1057/palgrave.abm.9200014.

Schlunze, R. D., Hyttel-Srensen, J., \& Ji, W. (2011). Working towards hybrid solutions: The possibility of an IHRM model in Japan. Ritsumeikan Business Journal, 5, 99-118.

Schwartz, S. H. (1999). A theory of cultural values and some implications for work. Applied Psychology, 48(1), 23-47. http://dx.doi.org/10.1080/026999499377655.

Simonin, B. L. (1999). Ambiguity and the process of knowledge transfer in strategic alliances. Strategic Management Journal, 20(7), 595-623. http://dx.doi.org/10.1002/(SICI)1097-0266(199907)20:7<595::AID-SMJ47>3.3. $\mathrm{CO} ; 2-\mathrm{X}$.

Swierczek, F. W., \& Onishi, J. (2003). Culture and conflict: Japanese managers and Thai subordinates. Personnel Review, 32(2), 187-210. http://dx.doi.org/10.1108/00483480310460216.

Tran, N. T. (1996). Tim ve ban sac van hoa Vietnam: Cai nhin he thong-loai hinh [Discovering the identity of Vietnamese culture: Typological-systematic views]. Ho Chi Minh city: Ho Chi Minh Publication.

Tran, N. T. (1999). Co so van hoa Vietnam [Vietnam's fundamental culture]. Ho Chi Minh city: Education Publication.

Trevor, M. (1983). Japan's reluctant multinationals: Japanese management at home and abroad. New York: St Martin's Press.

Yin, R. K. (2009). Case study research: Design and method (4th ed.). Thousand Oaks, California: Sage Publications.

Yoshino, M. Y. (1976). Japan's multinational enterprises. Cambridge: Harvard University Press. 